\title{
What's in Your Culture? Embracing Stability and the New Digital Age in Moving Colleges of Health Professions Virtually during the COVID-19 Pandemic: An Experiential Narrative Review
}

\author{
Melanie Poudevigne ${ }^{1, *(D)}$, Erika S. Armstrong ${ }^{2}{ }^{\circledR}$, Marisa Mickey ${ }^{3}$, Michelle A. Nelson ${ }^{1}$, Comfort N. Obi ${ }^{1}$, \\ Andrew Scott ${ }^{4}$ (D), Naquilla Thomas ${ }^{1}(\mathbb{D})$ and Tamara N. Thompson ${ }^{1}$ \\ 1 College of Health, Clayton State University, Morrow, GA 30260, USA; michellenelson@clayton.edu (M.A.N.); \\ comfortobi@clayton.edu (C.N.O.); naquillathomas@clayton.edu (N.T.); tamarathompson@clayton.edu (T.N.T.) \\ 2 College of Health Sciences, Texas Woman's University, Denton, TX 76204, USA; earmstrong@twu.edu \\ 3 School of Sport Science, Endicott College, Beverly, MA 01915, USA; mmickey@endicott.edu \\ 4 School of Sport, Health and Exercise Science, University of Portsmouth, Portsmouth PO1 2ER, UK; \\ andrew.scott@port.ac.uk \\ * Correspondence: mpoudevigne@clayton.edu
}

check for updates

Citation: Poudevigne, M.; Armstrong, E.S.; Mickey, M.; Nelson, M.A.; Obi, C.N.; Scott, A.; Thomas, N.; Thompson, T.N. What's in Your Culture? Embracing Stability and the New Digital Age in Moving Colleges of Health Professions Virtually during the COVID-19 Pandemic: An Experiential Narrative Review. Educ. Sci. 2022, 12, 137. https://doi.org/ 10.3390/educsci12020137

Academic Editors: Susie J. Schofield and Ahsan Sethi

Received: 16 December 2021

Accepted: 14 February 2022

Published: 18 February 2022

Publisher's Note: MDPI stays neutral with regard to jurisdictional claims in published maps and institutional affiliations.

Copyright: (C) 2022 by the authors. Licensee MDPI, Basel, Switzerland. This article is an open access article distributed under the terms and conditions of the Creative Commons Attribution (CC BY) license (https:// creativecommons.org/licenses/by/ $4.0 /)$.

\begin{abstract}
As traditional education transitioned from face-to-face interactions to virtual learning during the COVID-19 pandemic, faculty and staff in dental hygiene, nursing, and exercise science programs placed students at the center of every educational decision and promoted stability in learning with their commitments to excellence in teaching and the delivery of content using educational and communication technology. This experiential narrative review explains how faculty members and administrators addressed online education with technology specific to health professions and how universities managed to assist students with innovative services for mental health. It also provides an insight into how degree-specific academic personnel embraced technology-based hands-on activities in community health clinics and clinical laboratories, with sustainable and impactful lessons in equity, affordability, and transformative education. Finally, health administrators gather their top-10 leadership recommendations to continue moving forward during the pandemic and present a unique self-reflection on the process of caring considerations required for a successful experience for faculty members, staff, and students.
\end{abstract}

Keywords: academic leadership; COVID-19 pandemic; dental hygiene; nursing; sport health and exercise science; virtual learning

\section{Introduction}

The COVID-19 pandemic is an unfamiliar and uncertain public health event that is shaking countries to their core. It surpasses being labeled an emergency and during the spring of 2020, higher education organizations around the world had to enter into management crisis mode. In order to effectively navigate the new territory and adjust through this unprecedented upheaval, specific academic leadership skills were needed to survive and thrive. From a managerial perspective, proactive academic leaders connected with faculty members, staff, and students by exhibiting authenticity and transparency, distributing leadership responsibilities, and communicating [1]. They also applied skills for critical thinking, decision-making, agility, collaboration and coordination, active listening, technical training, and emotional intelligence [2]. These skills and characteristics are parallel to those of health professionals, especially for frontline workers in healthcare. Health professionals continue to demonstrate high levels of resilience and to exhibit a deliberate calm which can allow them to detach from dramatic situations to think objectively and rationally [3]. Cognitive behavioral science entered the life of health professions' academic 
leaders with the systematic use of the pause-assess-anticipate-act cycle [4]: clinical and hands-on learning was quickly and efficiently reassessed to provide students and faculty members with the necessary technological support. As new variants are announced and various mitigations are in place, health academicians and leaders are considering holistic views and embracing stability with different vantage points, troubleshooting and analyzing before proceeding with courses of action. From an educational effectiveness point of view, this article will review how to meaningfully engage students both from a mental health and technological angle. This article focuses on how virtual learning can be successfully executed in health programs, namely nursing, dental hygiene and exercise science with their respective clinical considerations. The authors have summarized leadership skills and abilities for program directors and chairs that were equally important in creating the much-desired stability for learning continuously and virtually.

\section{Addressing Mental Health in Higher Education}

The COVID-19 pandemic required health faculty members to become innovative, creative, and resourceful to educate and motivate students to continue their academic journeys. The pandemic presented health faculty members with the scholarly task of immediately adapting didactical and clinical courses. Ultimately, standards of excellence are mandated by various health program accreditations and specialty agencies. For example, in the USA, they are supported by the Committee on Accreditation for the Exercise Sciences (CoAES) under the auspices of the Commission on Accreditation of Allied Health Education Programs (CAAHEP), the Commission on Dental Accreditation (CODA) and the Quality and Safety Education for Nurses project. In response to the pandemic, these health authorities provided revised guidelines addressing the quality and safety competencies for students and proposed knowledge, skills and abilities for each competency asserting that each novice professional would continue to be prepared to deliver the various expected health care services. Even though revisions to protocols and new tutorials were publicly created and shared by the respective accreditation agencies [5-7] or on social media [8], health science faculty members became extremely V.O.C.A.L. (Visible, Organized, Compassionate, Analytical, Leaders) and fully embraced learning with digital tools as an opportunity for positive transformation [9].

Generally, students experience considerable stress in their personal and academic lives [10]. However, this stress was exacerbated by transitioning to virtual settings, especially for marginalized, underserved, or non-traditional students who often juggle multiple responsibilities and must be diligent with their time management while caring for others, personally and financially [11]. Digital social interactions were and remain, critical to ward off social isolation arising from travel bans, lockdowns, or quarantine requirements. The novelty of introducing new virtual platforms and committing to spending hours in front of a screen undeniably increased stress and anxiety levels both in students and faculty members [12] and had the potential to decrease academic performance and satisfaction if not carefully managed [13]. An overall decline in mental and physical health was also reported [14]. To counter the uncertainty, academic leaders recommended that faculty members increase the frequency of individual videoconferencing check-ins for academic and moral support [15] and campuses quickly offered some long-lasting solutions.

At the authors' institutions, Student Affairs including Campus Life and Psychological Services were instrumental in enhancing a sense of belonging among students, which included offering a variety of remote leisure activities and telehealth support services. Ortiz and Levine [16] describe guidelines in which to operate a university counseling clinic during a global pandemic. Psychological services across the world deployed access to free mental health applications to help with time management, body image, sleep, physical activity, nutrition, mindfulness, stress management, social and behavioral self-improvement, communication, interpersonal relationships, finances, and sexual health. Examples of applications introduced and now extensively used, include, but are not limited to: CampusWell [17], Breathe2Relax [18] (helps students learn the stress management skill called 
diaphragmatic breathing which decreases stress and helps with mood stabilization, anger control and anxiety management), Calm Harm [19] (helps students to learn to identify and manage their emotive responses with positive impact as well as track their progress), Clear Fear [20] (uses a cognitive behavioral framework to help students manage anxiety, fear and emotional responses), Happyfeed [21] (improves mental health by journaling on gratitude and daily moments of joy) and Sanvello [22] (provides clinically proven techniques based on cognitive behavioral therapy for dealing with stress, anxiety, depression and other emotions students might experience). Such services were key for integrative leadership success in addressing belongingness and isolation, especially in racial/ethnic minorities, underserved students, non-traditional adults, and essential student workers who have been documented to be at increased risk for substance abuse, suicidal ideation, and negative mental health outcomes [14].

Around the country, campus psychological services responded by creating a myriad of virtual reality rooms and providing an interactive health management experience for students and faculty members. Initially designed for the treatment of phobias [23], the use of virtual reality has expanded to other mental health disorders such as stress management, substance use disorders, eating disorders and anxiety [24]. Such virtual access provides campuses with options for healthcare delivery, given its potential to provide clinically relevant information associated with the assessment and treatment of people suffering from mental health ranging from episodes to disorders [25]. To foster self-reliance, belongingness and resiliency, incentives for participants who engage in activities enhancing connectedness provided the necessary motivation to become curious, venture electronically and participate actively. Pruitt et al. [26] provided an example of a successful intervention depicting the use of telehealth in suicide prevention in a marginalized population. While $2 / 3$ of the participants expressed greater social disconnect at the onset of the study, a striking $75 \%$ of participants successfully used the virtual services to enhance their mental health, reporting positive results.

"Table Talk" virtual sessions allowed leaders to assess campus community perceptions towards constituents' mental health amidst the COVID-19 pandemic. They also allowed students to go one step further in discussing their experience of social biases. To reduce the detachment of students from faculty members and other staff, these members of staff were invited to "special session" table talks to share their expertise, wisdom, personal COVID-19 experience and challenges with students to promote a sense of community and student support. Campus Life served as the command center, communicating with students via social media, emails, and texting to provide weekly COVID survival tips and resources available for academic, housing, food, and mental wellness challenges [27].

Across the world, online faculty members understood the unusual complexities experienced by students majoring in health professions and collectively and strategically implemented holistic interventions to support these students personally and professionally. Regular question-and-answer study sessions dubbed by some as "Happy Hours" were conducted virtually using non-traditional communication methods in order to improve upon learning outcomes and support academic success. These sessions were often conducted in the evenings or on weekends to accommodate health science students' working schedules [28]. In addition to teaching academic content, health science faculty members demonstrated caring for their students' mental health. This compassion has a tremendously positive effect on students' ability to perform academically, think critically, act appropriately, and become empathically present in the moment [29]. Examples of global social support geared to help students' mental health flourished during the pandemic: phone calls and texting became appropriate to promote students' emotional well-being using the theory of planned behavior [30]. While nurses and other allied health professionals joined to work relentlessly in clinics and hospitals around the world, health sciences and nursing faculty members transferred their set of professional (soft) skills to educate and support others and to foster change that ultimately reduces mental health-stigmatizing beliefs and attitudes [31], especially for underserved students. 


\section{Technology Democratization and Access}

The demand for affordable online learning has surged in the past two years. From telecommuting to virtual schooling, the global workforce is engaging more than ever via technology. Unfortunately, underserved populations, exacerbated by social inequalities, are at a disadvantage for successful online learning.

In remote and rural areas, the lack of high-speed internet access is a significant challenge. Laws passed during the 2019 session by some United States of America's General Assemblies required designated corporations to charge fair and reasonable pole attachment rates to broadband competitors from 2021 [32] (The term "pole attachment" means any attachment by a provider of telecommunications service to a pole, duct, conduit, or right-of-way owned or controlled by a utility company). Internet access is critical for educating marginalized populations and providing vital healthcare services via technology, significantly reducing the distance one must travel for self-care [33].

There is an opportunity to democratize technology, with online platforms providing easy access and inclusive environment to learn new skills. Women have been particularly affected during the pandemic: childcare closures and job search hiatus impacted many [34]. However, career advancement can be provided with online learning that in turn can stimulate career benefits especially for historically marginalized populations [35]. In that spirit, with efforts geared towards Diversity, Equity, \& Inclusion (DE\&I), dedicated Information Technology staff on campuses were recruited to host non-traditional Help Desk hours during which faculty members and students alike could seek assistance. This service was instrumental in contributing to a robust virtual learning environment, with in-person instruction shifting online and showcasing of various teaching, learning and assessment strategies available via videoconferencing, video productions and other learning management systems (LMS). Sitting examinations remotely affected students who had limited resources such as unreliable internet and Wi-Fi. Universities supported these students by creating hot spots both on campus and around the community [36]. For example, students could park and stay in their cars on campus to write examinations. To maintain examination integrity, as the lockdowns eased off, students were brought back to campus to sit for examinations only. In these cases, social distancing was enabled, and permanent recorded seating arrangements put in place to facilitate contact tracing if exposure was reported. The wearing of face masks was encouraged in universities without an indoor mask mandate. Compliance with mask-wearing in health science programs was excellent at the authors' universities: the students replicated positive mitigation behaviors found in their respective workplaces without arguing.

\section{Student Engagement and Technology in Higher Education}

Online communication media continues to change people's lives and as we embrace information technology-based learning processes, educational digital tools are employed widely for health professions in higher education. According to Wiyono et al. [37], these tools include the use of gamification (Kahoot [38], Jeopardy [39], Quizizz [40], BigBlueBotton [41], Schoology [42]); video production (Kaltura Capture [43]); videoconferencing (Microsoft Teams, Zoom, Google Meet, Google Classroom); instant messaging with Google Chat, WhatsApp, discussion boards, case studies, movie reviews and analyses; diverse interactive learning platforms (NearPod [44] and Lippincott CoursePoint+ with Picmonic [45], Prep U practice [46] and DocuCare Electronic Health Record [47]).

Lectures were posted online along with authorized copyrighted resources. This enabled students to shift from passively listening in class to becoming proactively involved in planning their education ahead of synchronous sessions. Open-ended questions were highly beneficial for student engagement synchronously. Aydemir et al. [48] found that open-ended questions encouraged students to contribute more, including those with limited knowledge of the concept because no answer is right nor wrong and students' interest in participating was increased. 
The use of break-out rooms became essential to enhance the necessary critical thinking involved in teamwork. Faculty members pre-selected students for each group to ensure inclusiveness and diversity [49]. Online disengagement and decreased attention are a reality for distracted students or those passively listening to class activities [50,51]. To encourage participation, the faculty implemented strategies such as taking attendance at random times and engaging students in answering questions by voice or in the chat. Other strategies included using breakout rooms for small group discussions, quick presentations in pairs or groups of three and the use of sharing knowledge to resolve case scenarios.

Students completed concept mapping for medical conditions beforehand to increase their knowledge and to prepare to learn for more complex scenarios [52]. As a result of time and laboratory capacity restrictions, faculty members significantly increased their workload to respect the mitigations in place and held multiple simulation sessions with small student teams. Courses with a service-learning component in the community shifted to using scenarios, virtual communities, analysis of public health-related movies, documentaries, and news items.

For grading and integrity, live proctoring on the LMS and writing tests using cameras and Respondus [53] were viable options that continued during the pandemic as health professions virtually migrated. Proctoring live examinations for large classes and establishing privacy to address an individual student during testing were limited and remain areas to be improved by EdTech companies in 2022.

The Need for Course Orientations during the Pandemic

To facilitate using the LMS more effectively, on the first day of the virtual class, faculty members provided students with a virtual orientation on how to navigate through the platform. For first time users, this step allowed them to become familiar with the course syllabus, individual and group assignments, discussion boards and expectations for the course. Hampton and El-Mallakh [54] confirmed that students in online courses already found group assignments problematic prior to the pandemic. Therefore, faculty members guided students on how to complete group assignments successfully using the myriad of technology cited above in the absence of face-to-face interactions. The orientation included a discussion centered on virtual classroom behavior and etiquette such as background noise control, dressing for class, class attendance and in-class communication. Students were referred to other course and college policies contained in college specific student handbooks which were posted on the LMS. With each subsequent day of class, students and faculty members enhanced their online presence and active participation.

The course syllabus, regarded as an agreement or contract which is binding between students and the college [55], reinforced the virtual activities to meet the set course objectives. The syllabus addresses the objectives, course requirements, methods of instruction, course materials (both required and recommended), grading scale and behavior expected of the students in the teaching and learning environment. With the transition from inperson to virtual, it became evident that aspects of the syllabus would change and require modifications to suit the new learning environment. Modes of instruction, course materials and activities, processes for examinations and method of communicating with faculty were therefore modified. With the absence of in-person interaction and regular scheduled office hours, the syllabus was clear on how students could contact the faculty. Flexible meeting times with students were maintained through emails, telephone calls, text messages and videoconferencing platforms $[9,56]$. Weekly online tutorials could also be arranged through a modern scheduling platform, Calendly and then conducted via a cloud-based peer-to-peer software platform or LMS [57].

\section{Promoting Student Success in Shifting Health Professional Programs Virtually}

\subsection{Nursing Programs}

Before the pandemic, nursing faculty members used more of the teacher-directed and controlled in-person teaching, with some student-directed non-traditional case studies, 
podcasts, concept mappings, discussion boards and game-based learning [58]. The impact of the COVID-19 outbreaks on the educational sector led to uncertainties and frantic efforts to shift to virtual learning within a short period of time [59]. These resulted in unprecedented challenges, especially for undergraduate nursing education, which had been rooted mostly in the traditional mode of classroom teaching and where students in-person clinical rotations were forced to stop [60]. The modes of instruction, learning strategies and lesson plans had to change within a short space of time to avoid disruption of students' learning. At the initial onset, clinical settings utilized for students' clinical rotations stopped allowing both students and instructors into their facilities.

For the nursing faculty, the goal was clear and unchanged, which was to ensure that program outcomes were met. The nursing program prepares students to embody 'caring' and 'compassion', and to use critical thinking, nursing therapeutics and evidence in providing safe care [61]. Other expected program outcomes include the ability to effectively use communication skills in caring for client and families and in collaborating with other members of the health care team [61]. The nursing faculty had to keep these outcomes in mind while exploring alternative teaching and learning modalities in a virtual environment. The transition to virtual learning entailed that the courses' syllabi be modified; however, the faculty had to identify and select appropriate alternatives that met the course objectives.

\subsubsection{Development and Accentuation of Academic Support Services}

It was certain that the transition from in-person to virtual learning would occur; however, the choice of using a customizable collaborative platform that integrates video conferencing, file storage and transfer with cloud capacity was made by the university administration. Transitioning from in-person to the virtual environment using this platform was challenging to both students and faculty members, especially given the short notice. It was most difficult because the majority of undergraduate nursing courses in seated programs were taught in-person and some of the nursing faculty had not taught fully online before. The nursing faculty's experiences with virtual teaching varies depending on the program and courses assigned. The American Association of Colleges of Nursing (AACN) [62] reports that there are about 996 undergraduate nursing programs in the United States offering the basic 4-year college education for high school graduates (or its equivalent) with no previous nursing experience. The first two years cover general courses in basic sciences, social sciences, nutrition, humanities, and ethics, among others. These preliminary courses can be taught by the nursing faculty or faculty members from other disciplines, in-person or online. Depending on the college or university, nursing classes can start in the first, second or third (junior) year; however, core nursing courses and the clinical nursing components are taught mostly in the last two years of the nursing program [62]. For core nursing courses taught in traditional classroom settings, faculty members had to rapidly learn new technologies to enable them to transition effectively and teach their content areas [63]. Faculty members received multiple virtual training workshops on how to teach using the customizable collaborative platform. Administrators effectively communicated on how to access these trainings. The messages included information on where faculty could access various workshops available for developing classes online, how to track the students that had logged into the online environment and the status of international students that the USA relies heavily on in meeting nurse staffing needs [64].

Faculty members had to keep abreast of the information sent out not solely for teaching effectiveness but because some students relied on faculty members for guidance in using the virtual platform. Virtual links to resources included how faculty members could navigate through the LMS and through web conferencing. A common website for the school of nursing was created to solely focus on these resources and provide the much-anticipated academic support for students. The fast-tracked training was executed by faculty members over a 2-week period during which faculty members were expected to be prepared to teach the second half of the semester virtually in Spring 2020. The faculty did not neglect to reach out for technical and technological support, training and mentoring in 2020, proving 
useful in 2021 when mitigations continued to stay in place in various places around the world $[63,65]$. Nonetheless, the fast transition was perceived to be overwhelming by students and faculty members [66].

\subsubsection{Student Engagement and Simulations}

Prior to the pandemic, the use of simulation laboratories provided a haven for nursing students to practice without fear of harm to patients. However, the cost of high-fidelity simulations posed challenges for schools and colleges with budgetary constraints. For students' clinical experience, clinical rotations in clinics and hospitals, in-person simulations in laboratories and virtual simulations (vSims) became popular. The vSims are web-based and accessible through the publisher, providing diverse patient scenarios of in-depth interactive experiences to enhance practical skills and to improve on clinical reasoning and decision-making skills [67-69]. They also help students increasingly develop confidence and competence with patient care [69].

With the pandemic, the clinical component of the course changed because students were not allowed in the clinical settings. The AACN released a statement asking nursing programs in the United States to have plans in place to address the students' clinical experience. Such plans should include "the expanded use of simulation, telehealth and virtual reality in keeping with best practices and guidelines from state boards of nursing and other regulatory bodies; the use of online resources for teaching clinical care; and online group chat features" [70] (p. 3). AACN is a national organization that represents and develops standards for nursing education in the United States. Considering the AACN statement, the focus shifted to the use of simulations (virtual and in-place) and case scenarios. Faculty members became more creative in developing alternatives to clinical rotations. Social distancing measures prescribed by Centers for Diseases Control and Prevention restricted the number of students allowed in the simulation laboratory at any one time. Additionally, restricted was the length of time the nursing faculty and the students could practice indoors in the simulation laboratory $(60 \mathrm{~min})$ to allow for proper ventilation to work afterwards.

\subsection{Dental Hygiene Programs}

The education and training surrounding the practice of dental hygiene had once been normalized as a program of study that is traditionally taught face-to-face. When the pandemic hit, the problem of postponing dental education and training presented a significant concern as the delay would not only interrupt the matriculation towards completion but also impact the number of dental hygiene graduates available for licensure to meet the growing demands involving access to dental care [71,72]. The profession of dental hygiene is in great demand as this is a preventive health field that focuses on diseases that not only affect the foundation of the smile but also overall health. Innovation to continue dental hygiene training and education was necessary and required. Embracing distance education through technology and providing real-time feedback became the gold standard to remain compliant with accreditation during the pandemic. Continuation of teaching fine motor skills in an innovative way and maintaining clinical hours motivated video recordings, virtual demonstrations, and formative feedback sessions [73].

The dental hygiene faculty accepted the challenge of distance education for traditionally face-to-face taught programs and forged ahead, realizing all programs of health were in the same predicament. Along with faculty members, students were motivated to continue learning in a modified way in the hope of graduation not being delayed. Home-based learning presented concerns at the onset of the shift to virtual learning; however, students ${ }^{\prime}$ uncertainties and perceptions varied [74].

\subsubsection{Development and Accentuation of Academic Support Services}

Shifting from face-to-face learning to a fully virtual format for skills-based training was the first of its kind in dentistry. As US dental programs accredited by CODA navigated 
the mandatory shift to online clinical activities, the program learning outcomes had to remain compliant with accreditation standards [75]. Dental hygiene programs around the nation worked closely with CODA to maintain standards and garner support as needed. Numerous modifications were made regarding the format of courses; however, there were no compromises to meeting the standards of the courses. Recognizing the impact of the pandemic, CODA proposed changes to its evaluation and operational policies and procedures to allow for temporary use of virtual and hybrid learning (combination of traditional faceto-face with online instruction) formats $[4,76]$. Specifically, the commission requested (1) an outline of the specific use of distance education within the curriculum, (2) documented methods of verifying student identity, (3) indication of any curricular content elimination or re-sequencing, and (4) a description of how compliance with standards were maintained. CODA is not prescriptive in dictating how to meet the given standards; therefore, faculty members were given the flexibility to engage students, however, individually deemed most appropriate. Temporarily unable to host traditional face-to-face courses, faculty members embraced distance education utilizing virtual platforms. With the approved flexibility from accreditation, the faculty were innovative hosting webinar learning sessions for students and requiring students to upload demonstration of skills videos. Webinars and video recordings were two examples of the innovations gleaned from the transition to distance education.

\subsubsection{Student Engagement and Simulation}

An exploration of technology proved to be the critical resource necessary to implement the transition from face-to-face to virtual and hybrid learning, specifically the exploration into telehealth and telemedicine. Presented with the challenge of continuing the education and training of dental hygiene skills, tele-dentistry via the use of institution-approved IT software was sourced. Specific to clinical skill acquisition, the use of an LMS and its screen sharing options proved essential. Integrating clinical skill instruction via distance learning utilizing a webcam positioned up close and centered changed the adage of face-to-face teaching for dental hygiene clinical skill training. Left with minimal-to-no options of continuing the tradition of hands-on skill instruction, it was necessary to incorporate software that allowed students to continue their practical training. Dental hygiene educational concepts routinely taught chairside were now innovatively offered through technological mediums that allowed for screen sharing, virtual demonstration, and video communication. Appendix A, Figure A1 depicts a dental hygiene faculty demonstrating clinical skill instrumentation on a dental model in a virtual learning session. In these types of sessions, faculty members would demonstrate the specific dental instrumentation skill (utilizing a dental model and webcam), then allow screen sharing for students to replicate what had been demonstrated. Similar to course textbooks, dental models and dental hygiene instruments are required course supplies and are purchased at the beginning of the program of study. The expectation of the virtual learning session was and still is that the learners set up their dental model and dental hygiene instrument kit ready to virtually showcase their skill following demonstration from the faculty.

With the continued and unchanged need for students to meet accreditation standards regarding clinical skill training, engagement via simulation patients and simulated activities were implemented. Simulation allowed for independent practice virtually guided by an observing faculty member as described by McComas et al. [73] and Newcomb et al. [77]. Students worked independently to showcase skill acquisition via the use of video recordings in Kaltura Capture [43] to be later uploaded and assessed by faculty members. The use of patient simulation allowed students to be engaged in a distance education format that introduced users to embrace telemedicine in dental care, innovation, and transition from the former way of patient care. Given these virtual experiences, the opportunity of playback for both clinical and didactic recorded content has drastically improved accessibility and thus shifted the direction of dental hygiene education. Students have commented favorably 
on being able to "go back" and listen to a lecture and "rewind" a skill being demonstrated. With these shared experiences, the future of dental hygiene education is evolving.

\subsubsection{Safety Considerations with Reopening University Clinics}

Many USA universities operate their own clinics, serving both children and adults with communication disorders, dental hygiene, and other health concerns. University clinics transitioned to teletherapy for existing clients with varying degrees of success. During the 2-week preparation period in spring 2020, administrators encouraged clinical supervisors to review the literature on best practices for teletherapy and tele-supervision and train clinical students to provide virtual clinical services as described by the American Speech-Language-Hearing Association and CODA $[75,78]$. The students readily adapted to this new modality and utilized the technology to provide interactive and effective therapy. At the same time, many clients embraced the change, grateful for the opportunity to continue services while staying at home. Added benefits included integrating family members into the sessions as well as incorporating therapy into real life activities such as grocery shopping.

At the beginning of the pandemic, the most challenging issue for clinics was securing personal protective equipment (PPE) for faculty members, staff, and students. At the time, vendors were not permitting bulk purchases and prices increased significantly, so students were required to purchase their own PPE. Administrators coordinated with vendors to secure the best pricing possible, and some universities reimbursed the students for their initial PPE purchases. Shortly thereafter, bulk purchasing of PPE became part of regular clinic operations. This included face masks (N95/KN95, level 3 surgical and transparent), face shields, gloves, and gowns, as well as additional equipment such as plexiglass dividers, HEPA air purifiers and disinfecting products. As health professional programs were the first programs approved to return to campus, administrators also prepared detailed procedures to mitigate exposures for all and included this information in patient consent forms. These procedures included staggered client arrival and transition times to decrease numbers in elevators and waiting rooms, temperature, and health checks for all upon arrival, using larger treatment rooms and limiting visitor access to facilitate contact tracing. All of this preparation and implementation allowed for a safe reopening. To date, university clinics continue to maintain these procedures; thus, minimal confirmed COVID-19 cases have been traced to these facilities.

\subsection{Exercise Science Programs}

\subsubsection{Development and Accentuation of Academic Services}

Adoption of Shorter Semesters

The COVID-19 adaptations were compounded by learning modules changing from a year-long to semester-long teaching structure in Europe and in the USA, changing from semester-long teaching structures to shorter semesters of eight weeks [79]. This necessitated moving from 16-24 weeks of 2 to $3 \mathrm{~h}$ in the classroom to 8 weeks of $3 \mathrm{~h}$ of either synchronous or asynchronous recorded lectures or tasks. Once lockdowns relaxed, one hour in the classroom per week was allowed in recognition of benefits of on campus sessions but allowing for air quality purposes. To support this reorganization, faculty and program coordinators discussed choices in learning outcome delivery for shortened recorded lectures and students were prompted to engage in much more directed independent learning and less synchronous contact time than usual [80]. Hybrid teaching was found to be best for exercise science programs.

\section{Adoption of Hybrid Teaching and the Flipped Classroom Model}

Graduate programs in Clinical Exercise Physiology are often supported by clinicians providing their expertise to students' development in understanding long-term conditions and their treatment with physical activity, with service-learning capacity happening at the local hospitals. In spring 2020, academic leaders needed to rapidly adapt to online delivery 
due to massively restricted access to campuses and hospitals [81]. Rather than attend the classroom, physicians and allied health clinicians specializing in respiratory, metabolic, cardiovascular, neurological, orthopedic, renal, and neoplastic presentations were requested to record lectures. Although this is no small challenge, flipping pathophysiology sections has been shown to be attractive to students and helped them to learn more and with less effort [82].

New teaching materials were developed to ensure the students received information relevant for their learning development and the learning tasks and synchronous sessions were constructed to provide a framework for addressing learning outcome requirements, using best practices for creating attractive and engaging virtual process-skills tutorials that provided students with an alternative method of learning [83]. Lectures were separated into smaller sections - up to $15 \mathrm{~min}$, preferably 5-10 min-to help the faculty deliver concise lectures so that the students' attention span could be maintained [84]. The audio-visual lectures were captured on Kaltura Capture or Panopto [43,85].

\subsubsection{Student Engagement \\ Synchronous and Directed Learning}

The lectures were accompanied by independent learning tasks to be completed weekly, such as guided learning tasks using pathology-specific National Institute for Health and Care Excellence: clinical guidance and Lancet review articles. This ensured active learning, allowing students to gauge their processing of the information being provided, facilitating critical thinking and problem-solving skills rather than passive learning [86]. Skill checks are usually in situ in the classroom; student laboratory fees in the USA were used to ship kits to students at home and to accommodate weekly synchronous interactive skill sessions with the faculty via the LMS. In Europe and Asia, self-directed learning was chosen during lockdowns as the preferred methods for effective learning [87] with evidence suggesting it is even more effective in distance learning than the traditional university setting [88]. Synchronous learning allowed for students to feel emotionally connected during periods of isolation [89]. Guest speakers such as physicians in nephrology and oncology were invited to join the LMS live to provide their experience and expertise to students through questions and answers for more complex long-term conditions, similar to the experience reported by the other health professionals' programs.

\section{Flipped Classroom Model}

The flipped classroom approach is defined as "an educational technique that consists of two-parts: interactive group learning activities inside the classroom and direct computer-based individual instruction outside the classroom" [90] (p. 4). Such a model in exercise sciences prompted faculty members to encourage students to make use of the required notional hours without the expectation for information to be passed 'via osmosis' during lectures, which was facilitated by the online lectures and study tasks. This was intended to encourage the students to engage with materials that they might usually have only used when preparing for their assessments, to reinforce the requirement to be lifelong independent learners and to increase student confidence in engaging with medical research and guidance. The many online learning activities were varied, with the successful aim of supporting the students' engagement in their learning, overcoming issues of speed of teaching delivery, students' attitude and struggles and stress of learning online. The short lectures, study tasks, classroom discussion and online tutorials enhanced the flexibility of learning compared to the largely singular approach of didactic lectures of previous years [88]. In retrospect, faculty members significantly increased their workload by managing the students' experience of online guided learning with the recorded lectures, independent learning tasks, and asynchronous feedback. However, recorded lectures have added value and will continue to be recorded for students who desire to continue studying online or simply for students who desire to review concepts in their own time. For universal access, the recordings should be correctly captioned. 


\section{Safety for in-Classroom Skill Checks Considerations}

For clinical exercise physiology programs, blended and connected learning can be retained to ensure that information is taught in varied styles. This includes didactic lectures, skills-checks and in-person classroom sessions as well as live online sessions to discuss ideas and concepts, ensuring that all learning styles and accessibility levels are considered.

To preserve a safe learning environment during the pandemic, hands-on laboratory (lab) sessions were split into blocks so that the same skills were run two weeks in a row: students were split into two cohorts, restricted in capacity to allow for physical distancing. One lab activity was completed in-person while another was completed as an individual computer-based activity. These activities were related to the specific unit outcomes covered in the lecture at that time. For example, the skeletal muscle unit was accompanied by an in-person grip strength and electromyography (EMG) activity as well as a rate-coding and frequency of stimulation computer-based activity. In-person labs involved handson activity with full PPE and sanitization procedures before, during and after the lab session. Tests that were performed in-person included but were not limited to: Wingate test, 1-mile walk test, Queens College step test, grip-strength and EMG, sight-hearing reflex, and cognitive function testing. Tests that included a respiratory component, such as the maximal oxygen uptake or maximal aerobic capacity $\left(\mathrm{VO}_{2}\right.$ max) test and spirometry, were included in the computer-based individual activities because of the high risk of COVID-19 transmission. For the $\mathrm{VO}_{2}$ max test, students were familiarized in person with the metabolic cart prior to the lab session. Each student was taught how to calibrate it in addition to setting an individual up for a test. For the computerized portion of the lab, students used a pre-recorded video to see the test in its entirety. Students were then provided with the subject's results. Questions based upon the results of the test were used as the assessment for this lab. These same results were then used in subsequent lectures when discussing chronic adaptations to aerobic exercise as a discussion activity. It should be noted that $\mathrm{VO}_{2}$ max testing resumed for the 2021-2022 academic year. In addition to the standard sanitation procedures, additional single use anti-bacterial filters are now used as part of the face mask. These anti-bacterial filters are manufactured through the metabolic cart company and are designed to fit the specific mask used. Some laboratories request a negative COVID-19 test before exercise testing.

Upon completion of each activity, students were required to answer reflection questions specific to that lab/skill. At the conclusion of each lab block, an activity was completed to connect unit lectures and labs together. Activity types included class discussions or case studies to enhance reflective observation. Reflection observation, when accompanied with active experimentation can help to increase student learning and understanding [91].

Another major consideration for these hands-on courses was student interaction. Generally, laboratory class sizes are small ( $\sim 60 \mathrm{sq}$. ft. per student). Splitting these groups into A and B groups created even smaller class sizes as the laboratory physical space for each student increased by three. This was advantageous for several reasons. First, it facilitated the flipped classroom design. Research has indicated that the flipped classroom typically works better in courses of smaller sizes [92]. Secondly, smaller sections increased student engagement. The lab sessions and lectures were delivered in a hybrid format with students spending half of their time online. It has been shown that during COVID-19, students felt disconnected from their peers and experienced loneliness [93]. As a result, it was important to create ample opportunities for students to engage with each other and practice their hands-on skills in a safe way. To accommodate this safely, students worked in pairs to complete labs. These pairings were chosen by the students and remained the same for the duration of the semester. This also allowed for easier contact tracing if necessary.

While these changes helped to facilitate exercise physiology lab courses, adaptations made to assessment and prescription courses by the fellow exercise science faculty must be recognized. The first adaptations included an increased focus on field-based tests such as push-up tests, sit-and-reach tests, and sit-up tests. These tests were performed either outside or in settings that allowed students to social distance. A second adaptation was 
to have students perform certain measurements on themselves or on manikin models if appropriate. It was found that these were particularly useful for skills that require a certain amount of time or practice attempts before becoming proficient. A common theme throughout exercise science faculty was the need to develop computer-based activities and lab activities that could provide active learning experiences for students if necessary. To date, there are no best practices for shifting lab-based skills to a computer model. The development of such a course may be warranted for the future.

\subsection{Perspectives on Internationalization of High Impact Practices}

Experiential learning has been a foundation of the undergraduate curriculum and has been deemed one of high impact in higher education [94]. Experiential learning opportunities, including internships and clinical practicum, can help undergraduate students develop practical skills that include communication, self-esteem, and awareness of work culture [95]. Enhanced motivation, graduation rates and entry into advanced degree programs have also been identified as outcomes of STEM related experiential learning opportunities [96].

As travel abroad becomes possible again to both established partnership universities and new partnerships, students will continue to gain internship experience within the health sciences field in an international setting. During their undergraduate career, students are required to complete practicum and internships. Many students choose to use an internship as an opportunity to travel abroad and gain experience within their field of studies in health and to experience new cultures and new healthcare systems [97].

Experiential learning opportunities abroad also allow students to increase their cultural competency. Previous research has indicated that providing opportunities for students in health sciences to engage with new cultural groups can help to increase cultural competence through enhanced understanding of differences and cultural integrity [98,99]. Moreover, providing these opportunities allows for the development of respect and positive attitudes towards the individuals that students encounter in the workplace and offers a better understanding of the challenges faced by special populations [100]. These capstone experiences provide students with DE\&I engagement opportunities that could not be created in the educational setting. Research has shown that increasing educational opportunities for DE\&I engagement learning opportunities can help achieve health equity, which is paramount in health professions [101,102].

\section{Administrative Lessons Learned during the Pandemic and the Importance of Values-Based Leadership}

The COVID-19 pandemic and shutdown tested the leadership skills of academic administrators as department chairs and deans endeavored to support faculty members, staff, and students while working within the constraints implemented by their university. Academic leaders faced the uncertainties of the virus, the academic and economic implications of the shutdown, and the seemingly daily changes in procedures. Faculty members and staff relied on their leaders for guidance and support, while higher level administrators worked with department chairs and deans to establish protocols for returning safely to campus.

Academic administrators faced a variety of leadership challenges and opportunities. Initially, the primary focus was supporting faculty members and students as they transitioned to online course delivery. Addressing how to safely reopen university health clinics that not only operate as critical training facilities for students but also provide much-needed health care services to individuals in the community was vital for patient care.

The leadership challenges administrators faced during the pandemic served to emphasize several key characteristics of an effective higher education leader. These lessons are not necessarily new, yet the unique experience of managing diverse health units during a shutdown provided a different perspective and highlighted the importance of valuesbased leadership [103]. Seven core values became fundamental to drive units in health professions and actions related to these programs' missions: caring, collaboration, creativ- 
ity, diversity, excellence, opportunity, and wellbeing [104]. In the following section, the authors emphasize the top ten crucial concepts that will boost faculty and staff morale moving forward.

\subsection{Trust in Your Faculty and Staff to Know How Best to Support the Students and Programs}

Since the faculty members and staff were more closely connected with the students, they were aware of how best to support student learning. The role of the department chair was to secure the requested resources and advocate with upper administration as needed. For example, the health science faculty incorporated simulations into the curriculum to allow the students to acquire mandatory hands-on hours and competencies. The faculty compiled and distributed lab materials so the students could participate in the hands-on lab experiences from their homes. This dedication, as well as the efficient clinic operations, has since allowed students to meet program accreditation requirements and graduate on time.

When the university initially cleared the students to return to campus for academic courses with COVID protocols in place, faculty members discussed whether to return or remain in virtual classes. Interestingly, decisions were mixed across programs. Each choice should be deemed appropriate for the specific program and supported by administrators for the best outcomes for learning and student success. Empowering faculty members and staff means accepting changes to programs' delivery.

\subsection{Give Faculty the Tools They Need to Be Effective Educators}

The choice of the most suitable delivery mode may vary from one unit to another. Some faculty members were already teaching online courses, so at the beginning of the shutdown therefore certain schedules did not change. Many exercise science programs already offered hybrid courses. This provided structure and a sense of continuity for both faculty members and students. Some universities were notebook universities and provided faculty members with in-home computers and/or laptops. Universities also provided faculty members and staff with portable whiteboards and document cameras, second computer screens and specialized instructional software, all directly shipped to faculty homes. A growing number of faculty members are becoming more interested in further developing the skills they acquired in managing online courses, even when returning to faceto-face teaching. Academic administrators should facilitate this professional development by supporting travel to or virtual attendance at, teaching conferences and investing in different technologies. In addition, administrators should organize opportunities for faculty members to share their knowledge with and learn from their colleagues.

\subsection{Communicate with Faculty and Staff Frequently}

One of the biggest losses during the shutdown was the "pop into the office" or "passing in the hallway" conversations. Before establishing goals and motivating faculty members and staff, leaders should share their point of view and communicate that perspective clearly. The process of "sensemaking" by Maitlis and Christianson [105] establishes a mutual understanding of a problem between leaders and workers and allows for a cohesive and organized approach to problem solving, essential during times of significant change [106] and when reliable information is not easily accessible.

\subsection{Be Clear and Transparent}

During the pandemic, there was a lot of uncertainty that included budget cuts and the potential for faculty and staff reductions. While higher administration was communicating information about the university in general, faculty members and staff needed to know what that meant for their own unit and specifically, for their individual jobs. During regular virtual meetings, administrators provided faculty members and staff with specific department budget information and ways in which units could weather the announced budget cuts. Administrators supported the clinical faculty and clinic staff who were 
concerned that they could not perform their regular job duties from home, providing them with the necessary resources.

Recognizing that staff and non-tenured faculty members are more vulnerable in the workplace, especially during times of crisis, means taking the time to consider the perspective of the least protected employees and addressing their concerns and situations openly [107].

\subsection{Be Flexible}

Many faculty members and staff were dealing with significant family upheavals, including home-schooling children and medical concerns. Administrators attempted to allow for as much flexibility in hours/schedules as possible so faculty members and staff could balance their work and personal responsibilities. Universities permitted a one-year extension on the faculty tenure clock if requested and allowed all faculty to count "accepted" presentations as "presented" toward promotion [108]. Administrators should continue to rethink traditional work schedules, especially for staff. Some staff may choose to telework while others would prefer working flexible hours including evenings or weekends. Academic leaders should extend this flexibility in thinking by mentoring faculty members in ways they can be flexible with their courses and students. This can include empowering faculty members to rethink their traditional teaching methodology and assessment measures and processes, embracing the technology available and the ways in which it can support a flexible academic environment $[109,110]$

\subsection{Foster Teamwork and Shared Leadership}

The pandemic created several challenges that were best addressed by faculty members working together to solve problems and assuming leadership of the situations. Due to the limited opportunities for students to earn clinical experiences, clinical faculty pulled together to provide them with alternatives. Faculty members devised plans to safely reopen community clinics to provide the experiences needed for the students to graduate. Some faculty members partnered with school districts to provide students and parents with additional hours to address their health and vaccination concerns. Exercise Science and other allied health faculty members coordinated programming virtually and in outdoor spaces. Within departments, faculty members who were more experienced in online teaching volunteered to mentor less experienced faculty members. Administrators should continue to create leadership opportunities for all faculty and staff, not just those in current leadership roles or who have expressed a desire to lead. While not everyone will move into administrative positions, having the opportunity to lead a committee or an initiative helps develop leadership and collaboration skills, which will serve them and your organization well [111].

\subsection{Show Students We Value Them as People}

Students from unprivileged and historically marginalized backgrounds often experience limited access to technology resources. Student services provided loaner laptops and other technological infrastructure such as hotspots around campus. Faculty members provided students with information about supports and services available to them through the university, including federal and university funding. Faculty members increased their workload by offering extra non-traditional time in virtual office hours and encouraged students to share their experiences with faculty members to determine the best way to support them.

The pandemic provided administrators with the opportunity to see and hear firsthand the personal living situations for many students. Rather than the students leaving their homes and coming to campus for their education, faculty members entered their personal (virtual) space as the students juggled both school and home life simultaneously. While universities are returning to face-to-face instruction, it is important that faculty members and administrators make more personal connections with students, acknowledge 
the significant burdens these students are carrying and adapt to support their academic success [112].

\subsection{Encourage Self-Care for Faculty and Staff}

While faculty members 'entered' students' personal lives, administrators also needed to acknowledge that faculty members and staff were functioning as instructors and support personnel from their own homes. For many, it was a challenge to separate work life from personal life as faculty members and staff dedicated so much of their time and energy to ensuring students successfully completed their programs. Empowering faculty members and staff to take breaks and recharge means modeling appropriate work-life balance and honoring their time away from the office [113].

\subsection{Practice Empathy and Compassion}

Throughout the lockdown and the gradual return to campus, faculty members, staff, and students struggled with unimaginable difficulties in both their personal and academic lives. People dealt with loss, fear, stress, anxiety, and uncertainties while attempting to maintain some semblance of normality. Administrators, faculty members, and staff emphasized empathy and compassion in working with students to successfully complete their semester. There is no reason why demonstrating empathy and compassion towards students, faculty members, and staff should stop. Such awareness means continuing to empathize with various situations and consider ways in which we can support them in achieving academic and professional goals [114].

\subsection{Be Open to Opportunities and a New Normal}

Simulations and telemedicine were not just necessary alternatives; they proved to be better modalities for many students and clients. Virtual meetings leveled the playing field among faculty members and staff from satellite campuses and in some ways promoted parity in discussions and decision-making when everyone was not in the same physical room. Higher education is changing, as are clinical health science programs. Based on students' success in distance learning and clinical skills acquisition during the pandemic, administrators may wish to implement new distance programs, providing the opportunity to reach students in rural and underserved communities while working with legislators to deliver the necessary broadband capacity [115].

\section{Conclusions}

The transition to virtual learning for healthcare programs provided opportunities for faculty members to expand their knowledge in distance education. Faculty members learned to explore resources that would not have been considered prior to the pandemic. Exploring these opportunities and resources, in turn, resulted in stress and anxiety; however, they also provided a way forward for technological democratization that seemed convenient and appropriate for higher education. Faculty members have proven that they can successfully teach from the comfort of their homes in addition to taking care of day-to-day activities and their personal lives at the same time. With much needed flexibility in content delivery as a direct impact of the pandemic, the shift to virtual and hybrid formats allowed for the discovery of new and innovative modalities to not only train clinical students outside of the traditional laboratory setting but also observe and evaluate their learning. The focus on clinical concepts allowed for full use of technology that proved to be value added, especially regarding the concept of time management. Specifically, the expectation of students to arrive to class prepared and ready for active learning was reinforced as the standard.

For the 2022 academic year, mitigation measures should not be dropped. These measures include recommendations that campus communities will continue to be vaccinated, wear facemasks, remain socially distant and wash hands frequently with soap and water. Hand sanitizers should be placed around campus and tests for COVID-19 performed 
frequently using available on-campus lateral flow tests or state and local agencies. Lab and other clinical courses will move towards pre-COVID-19 designs; however, lessons learned from the pandemic remain. The primary lesson learned was to be more flexible (in course approach, delivery, and timetables). The flipped classroom design facilitated flexibility for information delivery and approach. A second lesson learned from the pandemic is that educators have so many tools and technologies to disseminate information and it would be disadvantageous to go back to the "traditional" lecture and lab approach used pre-pandemic. Online tools and technologies can be valuable in providing further understanding of hard-to-grasp concepts in health professions. Moreover, these tools can be used to increase student engagement and practical learning experiences. Administrators should plan budgets accordingly. Thirdly, the pandemic has provided students studying and training in the field of health sciences with first-hand experience on how scientific research is conducted and disseminated to a larger audience. Furthermore, it has created opportunities for students to critically think about the information presented in the media and use peer-reviewed research to either agree or refute statements made. The pandemic has provided an opportunity for health science students to think critically about human behaviors and how various aspects of this pandemic will transform health professions in the years to come. Similarly, academic leaders have been able to reimagine health care education to better support students and future patients in the post-pandemic world. Finally, by operating within a framework of values-based leadership and focusing on the programs ${ }^{\prime}$ core missions, together administrators, faculty members and staff will successfully lead these transformational initiatives.

Author Contributions: Conceptualization, M.P.; methodology, M.P., E.S.A., M.M., M.A.N., C.N.O., A.S., N.T. and T.N.T.; software, M.P., E.S.A., M.M., M.A.N., C.N.O., A.S., N.T. and T.N.T.; validation, M.P., E.S.A., M.M., M.A.N., C.N.O., A.S., N.T. and T.N.T.; resources, M.P., E.S.A., M.M., M.A.N., C.N.O., A.S., N.T. and T.N.T.; writing-original draft preparation, M.P., E.S.A., M.M., M.A.N., C.N.O., A.S., N.T. and T.N.T.; writing-review and editing, M.P., E.S.A., M.M., M.A.N., C.N.O., A.S., N.T. and T.N.T.; visualization, N.T. All authors have read and agreed to the published version of the manuscript.

Funding: This review did not receive any external funding.

Institutional Review Board Statement: This is a review based on administrative decisions taken at the four institutions. The authors have willingly entered the writing at their own will. There is no identifiable dataset to share with the public.

Informed Consent Statement: Written consent has been obtained from the authors to publish this paper.

Data Availability Statement: The review did not report any data.

Conflicts of Interest: The authors declare no conflict of interest.

\section{Appendix A}

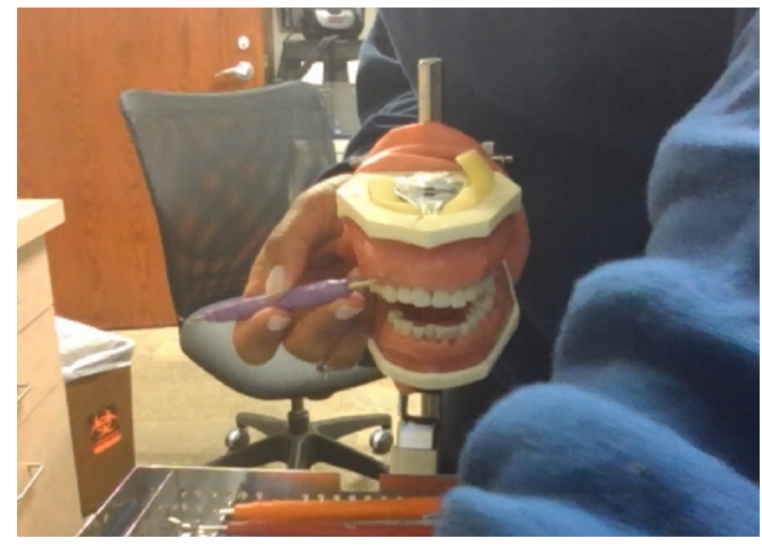

Figure A1. Dental hygiene virtual instrumentation. 


\section{References}

1. Fernandez, A.A.; Shaw, G.P. Academic leadership in a time of crisis: The coronavirus and COVID-19. J. Leadersh. Stud. 2020, 14, 39-45. [CrossRef]

2. Cairns, T.D. Emergency management planning and leadership are critical to business performance. Employ. Relat. Today 2017, 44, 5-13. [CrossRef]

3. Jha, M.K. An Integrated Framework of Leadership for Healthcare Organizations to Navigate Through COVID-19 Crisis. Asia Pac. J. Health Manag. 2021, 16, 16-20. [CrossRef]

4. Harish, V.; BCompH. The syndemics of emergency: How COVID-19 demands a holistic view of public health promotion and preparedness. Am. J. Public Health 2021, 111, 353-354. Available online: https:/ /www.proquest.com/scholarly-journals/syndemicsemergency-how-covid-19-demands-holistic/docview/2516961968/se-2?accountid=10139 (accessed on 7 December 2021). [CrossRef]

5. Commission on Accreditation of Allied Health Education Programs. (n.d.) COVID-19 Information. Available online: https:/ / www.caahep.org/getattachment/ About-CAAHEP/COVID-19-Information/CAAHEP-COVID-statement-approved111921.pdf.aspx (accessed on 7 December 2021).

6. Commission on Dental Accreditation. (n.d.) COVID-19 Updates. Available online: https://coda.ada.org/en/accreditation/ accreditation-news/covid-19-updates (accessed on 7 December 2021).

7. American Association of Colleges of Nursing. (n.d.) Coronavirus Resources for Nurse Educators. Available online: https: //www.aacnnursing.org/News-Information/COVID-19 (accessed on 7 December 2021).

8. American College of Sports Medicine Members: Faculty. (n.d.) Private Group [842304139578812]. Facebook. Available online: https:/ / www.facebook.com/groups/842304139578812/ (accessed on 7 December 2021).

9. Heyer, J.A.; Summerlin, C.; Vargovich, S. The 13 Cs of Nursing During COVID-19: Nursing Faculty Collaboratives. ABNF J. 2021, 32, 17-22. Available online: https:/ / search.ebscohost.com/login.aspx?direct=true\&AuthType=ip, shib\&db=a9h\&AN=151476 895\&site $=$ ehost-live\&scope $=$ site (accessed on 7 December 2021).

10. Hagler, D.; Morris, B. Learning environment and teaching methods. In Teaching in Nursing and Role of the Educator: The Complete Guide to Best Practice in Teaching, Evaluation, and Curriculum Development, 2nd ed.; Marilyn, H., Oermann, J.C., De Gagne, B., Cusatis, P., Eds.; Springer Publishing Company: New York, NY, USA, 2018; pp. 47-52.

11. Fogg, N.; Wilson, C.; Trinka, M.; Campbell, R.; Thomson, A.; Merritt, L.; Tietze, M.; Prior, M. Transitioning from direct care to virtual clinical experiences during the COVID-19 pandemic. J. Prof. Nurs. 2020, 36, 685-691. [CrossRef]

12. Metzler, M.; Esmat, T.A.; Langdon, J.; Edwards, O.V.; Carruth, L.; Crowther, K.; Spinks, M.L. The Impact of Transitioning to Emergency Remote Instruction on Perceptions of Preparation, Institutional Support and Teaching Effectiveness. Coll. Teach. 2021, 1-12. [CrossRef]

13. Oducado, R.M.; Estoque, H. Online Learning in Nursing Education during the COVID-19 Pandemic: Stress, Satisfaction, and Academic Performance. J. Nurs. Pract. 2021, 4, 143-153. [CrossRef]

14. Lancaster, M.; Arango, E. Health and emotional well-being of urban university students in the era of COVID-19. Traumatology 2021, 27, 107-117. [CrossRef]

15. Ramos-Morcillo, A.J.; Leal-Costa, C.; Moral-García, J.E.; Ruzafa-Martínez, M. Experiences of nursing students during the abrupt change from face-to-face to e-learning education during the first month of confinement due to COVID-19 in Spain. Int. J. Environ. Res. Public Health 2020, 17, 5519. [CrossRef]

16. Ortiz, A.; Levine, M. Operating a University Counseling and School Psychology Training Clinic in a Global Pandemic. Contemp. Sch. Psychol. 2021, 1-15. [CrossRef] [PubMed]

17. CampusWell. [Mobile Application]. 2021. Available online: https://www.campuswell.com/get-the-app/ (accessed on 16 December 2021).

18. Breathe2Relax. [Mobile Application]. 2021. Available online: https://au.reachout.com/tools-and-apps/breathe2relax (accessed on 16 December 2021).

19. Calm Harm. [Mobile Application]. 2021. Available online: https://calmharm.co.uk/ (accessed on 16 December 2021).

20. Clear Fear. [Mobile Application]. 2021. Available online: https://www.clearfear.co.uk/ (accessed on 16 December 2021).

21. Happyfeed. [Mobile Application]. 2021. Available online: https://www.happyfeed.co/ (accessed on 16 December 2021).

22. Sanvello. [Mobile Application]. 2021. Available online: https://www.sanvello.com/ (accessed on 16 December 2021).

23. Rizzo, A.; John, B.; Newman, B.; Williams, J.; Hartholt, A.; Lethin, C.; Buckwalter, J.G. Virtual reality as a tool for delivering PTSD exposure therapy and stress resilience training. Mil. Behav. Health 2012, 1, 52-58. [CrossRef]

24. Fleming, T.M.; Bavin, L.; Stasiak, K.; Hermansson-Webb, E.; Merry, S.N.; Cheek, C.; Lucassen, M.; Lau, H.M.; Pollmuller, B.; Hetrick, S. Serious games and gamification for mental health: Current status and promising directions. Front. Psychiatry 2017, 7, 215. [CrossRef] [PubMed]

25. Emmelkamp, P.M.; Meyerbröker, K. Virtual reality therapy in mental health. Annu. Rev. Clin. Psychol. 2021, 17, 495-519. [CrossRef] [PubMed]

26. Pruitt, Z.; Chapin, K.P.; Eakin, H.; Glover, A.L. Telehealth during COVID-19: Suicide prevention and American Indian communities in Montana. Telemed. e-Health 2021. [CrossRef] [PubMed]

27. Lederer, A.M.; Hoban, M.T.; Lipson, S.K.; Zhou, S.; Eisenberg, D. More than inconvenienced: The unique needs of US college students during the COVID-19 pandemic. Health Educ. Behav. 2021, 48, 14-19. [CrossRef] 
28. Morrone, M.C.; Young, C.J. Prologue: Our Journey through the Pandemic. J. Teach. Learn. Technol. 2021, 10. Available online: https://scholarworks.iu.edu/journals/index.php/jotlt/article/view/32314 (accessed on 9 December 2021).

29. Katz, V.S.; Jordan, A.B.; Ognyanova, K. Digital equity, faculty communication, and remote learning experiences during the COVID-19 pandemic: A survey of U.S. undergraduates. PLoS ONE 2021, 16, e0246641. [CrossRef]

30. Sheldon, K.M.; Yu, S.C. Methods of gratitude expression and their effects upon well-being: Texting may be just as rewarding as and less risky than face-to-face. J. Posit. Psychol. 2021, 1-11. [CrossRef]

31. Hicks, L.J.; Caron, E.E.; Smilek, D. SARS-CoV-2 and learning: The impact of a global pandemic on undergraduate learning experiences. Scholarsh. Teach. Learn. Psychol. 2021. [CrossRef]

32. Nussbaum, K.; Cline, D. A Recent Broadband Availability Map from the Georgia Department of Community Affairs Shows that of the More Than 507,000 Homes and Businesses Lacking Access to Reliable Broadband, Nearly 70 Percent Are in Rural Georgia. 2020. Available online: https:/ / www.govtech.com/network/how-is-georgia-tackling-rural-internet-service-deserts.html (accessed on 7 December 2021).

33. Jennett, P.A.; Hall, L.A.; Hailey, D.; Ohinmaa, A.; Anderson, C.; Thomas, R.; Young, B.; Lorenzetti, D.; Scott, R.E. The socioeconomic impact of telehealth: A systematic review. J. Telemed. Telecare 2003, 9, 311-320. [CrossRef]

34. Alon, T.; Doepke, M.; Olmstead-Rumsey, J.; Tertilt, M. The impact of COVID-19 on Gender Equality (No. w26947). Natl. Bur. Econ. Res. 2020. Available online: https:/ / www.nber.org/system/files/working_papers/w26947/w26947.pdf (accessed on 7 December 2021).

35. Kizilcec, R.F.; Makridis, C.A.; Sadowski, K.C. Pandemic response policies' democratizing effects on online learning. Proc. Natl. Acad. Sci. USA 2021, 118, e2026725118. [CrossRef] [PubMed]

36. Ratledge, A.; Dalporto, H.; Lewy, E. COVID-19 and Rural Higher Education: Rapid Innovation and Ideas for the Future. Issue Focus. In MDRC; 2020. Available online: https: / / files.eric.ed.gov / fulltext/ED608307.pdf (accessed on 8 December 2021).

37. Wiyono, B.B.; Indreswari, H.; Prestiadi, D. The Use of Technology-Based Communication Media in The Teaching-Learning Interaction of Educational Study Programs in The Pandemic of COVID-19. In Proceedings of the 2021 IEEE 11th International Conference on Electronics Information and Emergency Communication (ICEIEC) 2021, Beijing, China, 18-20 June 2021; pp. 1-5.

38. Kahoot! [Computer Software]. 2013. Available online: https://kahoot.com/ (accessed on 13 December 2021).

39. Jeopardy. [Computer Software]. 2013. Available online: https://www.jeopardyapp.com/ (accessed on 13 December 2021).

40. Quizizz. [Computer Software]. 2015. Available online: https://quizizz.com/ (accessed on 13 December 2021).

41. BigBlueBotton. [Computer Software]. 2011. Available online: https:/ /bigbluebutton.org/ (accessed on 13 December 2021).

42. Schoology. [Computer Software]. 2009. Available online: https://www.schoology.com/ (accessed on 13 December 2021).

43. Kaltura Capture. [Computer Software]. 2006. Available online: https://corp.kaltura.com/video-content-management-system/ personal-video-capture/ (accessed on 13 December 2021).

44. Nearpod. [Computer Software]. 2016. Available online: https://nearpod.com/teach-b (accessed on 13 December 2021).

45. Picmonic. [Computer Software]. 2011. Available online: https://www.picmonic.com/ (accessed on 13 December 2021).

46. Prep-U. [Computer Software]. 2009. Available online: https://thepoint.lww.com/prepu-instructorfaq-answers (accessed on 13 December 2021).

47. DocuCare. [Computer Software]. 2018. Available online: https://www.wolterskluwer.com/en/solutions/lippincott-nursingfaculty/lippincott-docucare/ (accessed on 13 December 2021).

48. Aydemir, M.; Kurşun, E.; Karaman, S. Question-Answer Activities in Synchronous Virtual Classrooms in Terms of Interest and Usefulness. Open Prax. 2016, 8, 9-19. [CrossRef]

49. Boys, J. Exploring Inequalities in the Social, Spatial and Material Practices of Teaching and Learning in Pandemic Times. Postdigit. Sci. Educ. 2022, 4, 13-32. [CrossRef]

50. Fabriz, S.; Mendzheritskaya, J.; Stehle, S. Impact of Synchronous and Asynchronous Settings of Online Teaching and Learning in Higher Education on Students' Learning Experience During COVID-19. Front. Psychol. 2021, 12, 733554. [CrossRef] [PubMed]

51. Rapanta, C.; Botturi, L.; Goodyear, P.; Guàrdia, L.; Koole, M. Balancing technology, pedagogy and the new normal: Post-pandemic challenges for higher education. Postdigit. Sci. Educ. 2021, 3, 715-742. [CrossRef]

52. Kinchin, I.M.; Hay, D.B.; Adams, A. How a qualitative approach to concept map analysis can be used to aid learning by illustrating patterns of conceptual development. Educ. Res. 2000, 42, 43-57. [CrossRef]

53. Respondus. [Computer Software]. 2000. Available online: https://web.respondus.com/ (accessed on 16 December 2021).

54. Hampton, D.C.; El-Mallakh, P. Opinions of online nursing students related to working in groups. J. Nurs. Educ. 2017, 56, 611-616. [CrossRef]

55. Comer, A.R. The Syllabus as a Contract. Chronicle.com. 2016. Available online: http://www.chronicle.com/article/The-Syllabusas-a-Contract/237251 (accessed on 8 December 2021).

56. Miller, A.N.; Sellnow, D.D.; Strawser, M.G. Pandemic pedagogy challenges and opportunities: Instruction communication in remote, HyFlex, and BlendFlex courses. Commun. Educ. 2021, 70, 202-204. [CrossRef]

57. Calendly. [Computer Software]. 2010. Available online: https:// calendly.com/ (accessed on 13 December 2021).

58. Arruzza, E.; Chau, M. A scoping review of randomised controlled trials to assess the value of gamification in the higher education of health science students. J. Med. Imaging Radiat. Sci. 2021, 52, 137-146. [CrossRef] [PubMed]

59. Nentin, F.; Gabbur, N.; Katz, A. A Shift in Medical Education During the COVID-19 Pandemic. Adv. Exp. Med. Biol. 2021, 1318, 773-784. [CrossRef] 
60. Blevins, S. The Impact of COVID-19 on Nursing Education. Medsurg Nurs. 2021, 30, 145-146. Available online: https:// www.proquest.com/scholarly-journals/impact-covid-19-on-nursing-education/docview /2517546893/se-2?accountid=10139 (accessed on 7 December 2021).

61. Clayton State University. School of Nursing. 2021. Available online: https://catalog.clayton.edu/academic-catalog/health/ nursing/\#generalinformationtext-otp1 (accessed on 7 December 2021).

62. American Association of Colleges of Nursing [AACN]. Nursing Education Programs. Baccalaureate Education. 2021. Available online: https:/ / www.aacnnursing.org/Nursing-Education-Programs/Baccalaureate-Education (accessed on 7 December 2021).

63. Kerr-Sims, S.; Baker, D. Faculty perceptions of teaching online during the COVID-19 university transition of courses to an online format. J. Teach. Learn. Technol. 2021, 10, 337-353. [CrossRef]

64. McKitterick, D.J.; Peters, M.D.; Corsini, N.; Chiarella, M.; Eckert, M. International nursing students' and new graduates' experiences of transition to the nursing workforce: A scoping review protocol. JBI Evid. Synth. 2021, 19, 874-882. [CrossRef] [PubMed]

65. Howe, D.L.; Heitner, K.L.; Dozier, A.; Silas, S. Health Professions Faculty Experiences Teaching Online During the COVID-19 Pandemic. ABNF J. 2021, 32, 6-11. Available online: https: / / web.s.ebscohost.com/ehost/pdfviewer/pdfviewer?vid=0\&sid=a7 5d1452-98f0-42db-8df7-e1c8c6d81223\%40redis (accessed on 8 December 2021).

66. Iheduru-Anderson, K.; Foley, J. Transitioning to full online teaching during COVID-19 crisis: The associate degree nurse faculty experience. Glob. Qual. Nurs. Res. 2021, 8, 1-14. [CrossRef] [PubMed]

67. Cant, R.; Cooper, S. Simulation based learning in nurse education: Systematic review. J. Adv. Nurs. 2010, 66, 3-15. [CrossRef] [PubMed]

68. Padilha, J.M.; Machado, P.P.; Ribeiro, A.; Ramos, J.; Costa, P. Clinical virtual simulation in nursing education: Randomized controlled trial. J. Med. Internet Res. 2019, 21, e11529. [CrossRef] [PubMed]

69. Turrise, S.; Thompson, C.; Hepler, M. Virtual simulation: Comparing critical thinking and satisfaction in RN-BSN Students. Clin. Simul. Nurs. 2020, 46, 57-61. [CrossRef]

70. American Association of Colleges of Nursing. Considerations for COVID-19 Preparedness and Response in U.S. Schools of Nursing. American Association of Colleges of Nursing. 2020. Available online: https://www.aacnnursing.org/NewsInformation/COVID-19/AACN-Recommendations (accessed on 8 December 2021).

71. Elangovan, S.; Mahrous, A.; Marchini, L. Disruptions during a pandemic: Gaps identified and lessons learned. J. Dent. Educ. 2020, 84, 1270-1274. [CrossRef]

72. Hassan, M.G.; Amer, H. Dental Education in the Time of COVID-19 Pandemic: Challenges and Recommendations. Front. Med. 2021, 8, 648899. [CrossRef] [PubMed]

73. McComas, M.J.; Barragato, A.K.; Kinney, J. No skills left behind: Online teaching and learning in preclinical dental hygiene. J. Dent. Educ. 2021, 85, 1936-1937. [CrossRef] [PubMed]

74. Mutluay, A.T.; Mutluay, M. Educational concerns and awareness level among dental hygiene students during the COVID-19 pandemic. Int. Dent. Hyg. 2021, 1-9. [CrossRef] [PubMed]

75. Accreditation Standards for Dental Hygiene Education Programs. 2013. Available online: https://coda.ada.org/ \{\}$/$ media/ CODA/Files/dental_hygiene_standards.pdf?la=en (accessed on 15 December 2021).

76. Saichaie, K. Blended, Flipped, and Hybrid Learning: Definitions, Developments, and Directions. New Dir. Teach. Learn. 2020, 2020, 95-104. [CrossRef]

77. Newcomb, T.L.; Bruhn, A.M.; Suedbeck, J.; Hunt, A.W. Make a Patient (MAP): A simulation-based solution for clinical competency in dental hygiene students. J. Dent. Educ. 2021. [CrossRef] [PubMed]

78. American Speech-Language-Hearing Association Practice Portal. 2021. Available online: www.asha.org/Practice-Portal/ Professional-Issues/Telepractice (accessed on 9 December 2021).

79. Crawford, J.; Butler-Henderson, K.; Rudolph, J.; Malkawi, B.; Glowatz, M.; Burton, R.; Magni, P.A.; Lam, S. COVID-19: 20 countries' higher education intra-period digital pedagogy responses. J. Appl. Learn. Teach. 2020, 3, 1-20. [CrossRef]

80. Yan, E.M.Y. Embracing Digital Teaching and Learning: Innovation Upon COVID-19 in Higher Education. In COVID-19 Pandemic, Crisis Responses and the Changing World; Zhao, S.X., Wong, J.H., Lowe, C., Monaco, E., Corbett, J., Eds.; Springer: Singapore, 2021. [CrossRef]

81. Watermeyer, R.; Crick, T.; Knight, C.; Goodall, J. COVID-19 and digital disruption in UK universities: Afflictions and affordances of emergency online migration. High. Educ. 2021, 81, 623-641. [CrossRef] [PubMed]

82. Herrero, J.I.; Quiroga, J. Flipped classroom improves results in pathophysiology learning: Results of a nonrandomized controlled study. Adv. Physiol. Educ. 2020, 44, 370-375. [CrossRef]

83. Kramer, M.; Olson, D.; Walker, J.D. Design and assessment of online, interactive tutorials that teach science process skills. CBE Life Sci. Educ. 2018, 17, ar19. [CrossRef] [PubMed]

84. Geri, N.; Winer, A.; Zaks, B. A learning analytics approach for evaluating the impact of interactivity in online video lectures on the attention span of students. Interdiscip. J. E-Learning Learn. Objects 2017, 13, 215-228. [CrossRef]

85. Panopto. [Computer Software]. 2007. Available online: https://www.panopto.com/ (accessed on 13 December 2021).

86. Singh, J. Enhancing Student Success in Health Care Programs: Active Learning in a Hybrid Format. In J. Instr. Pedagog.; $2017 ; 18$. Available online: https:/ / files.eric.ed.gov/fulltext/EJ1182732.pdf (accessed on 9 December 2021). 
87. Nasri, N.M.; Halim, L.; Abd Talib, M.A. Self-directed learning curriculum: Students' perspectives of university learning experiences. J. Learn. Instr. 2020, 17, 227-251. [CrossRef]

88. Khalid, M.; Bashir, S.; Amin, H. Relationship between Self-Directed Learning (SDL) and Academic Achievement of University Students: A Case of Online Distance Learning and Traditional Universities. In Bull. Educ. Res.; 2020; 42, pp. 131-148. Available online: https:/ / files.eric.ed.gov/fulltext/EJ1281053.pdf (accessed on 9 December 2021).

89. Jiang, M.; Koo, K. Emotional presence in building an online learning community among non-traditional graduate students. In Online Learn.; 2020; 24, pp. 93-111. Available online: https:/ / files.eric.ed.gov/fulltext/EJ1277442.pdf (accessed on 9 December 2021). [CrossRef]

90. Lo, C.K.; Hew, K.F. A critical review of flipped classroom challenges in K-12 education: Possible solutions and recommendations for future research. Res. Pract. Technol. Enhanc. Learn. 2017, 12, 4. [CrossRef] [PubMed]

91. Mazerolle, S.M.; Bowman, T.G.; Benes, S.S. Reflective observation in the clinical education setting: A way to promote learning. Athl. Train. Educ. J. 2015, 10, 32-38. [CrossRef]

92. Hall, A.A.; DuFrene, D.D. Best practices for launching a flipped classroom. Flip. Classr. Pract. 2016, 79, 234-242. [CrossRef]

93. Alhammadi, S. The effect of COVID-19 pandemic on learning quality and practices in higher education- using deep and surface approaches. Educ. Sci. 2021, 11, 462. [CrossRef]

94. Chorazy, M.L.; Klinedinst, K.S. Learn by doing: A model for incorporating high-impact experiential learning into an undergraduate Public Health curriculum. Front. Public Health 2019, 7, 31. [CrossRef]

95. Malone, J.J. Sport science internships for learning: A critical view. Adv. Physiol. Educ. 2017, 41, 569-571. [CrossRef] [PubMed]

96. Crowe, M.; Brakke, D. Assessing the impact of undergraduate research experiences on Students: An overview of current literature. Counc. Undergrad. Res. Q. 2008, 28, 43-50. Available online: https://www.cur.org/what/publications/journals/search/?F_Sort= PostDate\&SearchBy=Author\&SearchField=crowe\&Boolean=AND\&JOurnal=CUR\%20Quarterly, \%20SPUR\&SortOrder=DESC $($ accessed on 9 December 2021).

97. Oliphant, J.B. Health sciences students' interest in and opinions about global health experiences. Educ. Plan. 2018, 25, 33-54. Available online: https:/ /scholarworks.rit.edu/article/1851/ (accessed on 9 December 2021).

98. Chau, K.L. A model for teaching cross-cultural practice in social work. J. Soc. Work Educ. 1990, 2, 124-133. [CrossRef]

99. Kratzke, C.; Bertolo, M. Enhancing students' cultural competence using cross-cultural experiential learning. J. Cult. Divers. 2013, 20, 107-111.

100. Sharma, N.J.; LaLinde, P.S.; Brosco, J.P. What do residents learn by meeting with families of children with disabilities? A qualitative analysis of an experiential learning module. Pediatr. Rehabil. 2006, 9, 185-189. [CrossRef]

101. Lyman, B.; Parchment, J.; George, K.C. Diversity, equity, inclusion: Crucial for organizational learning and health equity. Nurse Lead. 2021, 1-4. [CrossRef]

102. Kumanyika, S.K.; Yancey, A.K. Physical activity and health equity: Evolving the science. Am. J. Health Promot. 2009, 23, S4-S7. [CrossRef]

103. Copeland, M.K. The emerging significance of values based leadership: A literature review. Int. J. Leadersh. Stud. 2014, 8, 105. Available online: https://www.regent.edu/acad/global/publications/ijls/new/vol8iss2/6-Copeland.pdf (accessed on 9 December 2021).

104. Geerts, J.M.; Kinnair, D.; Taheri, P.; Abraham, A.; Ahn, J.; Atun, R.; Barberia, L.; Best, N.J.; Dandona, R.; Dhahri, A.A.; et al. Guidance for Health Care Leaders during the Recovery Stage of the COVID-19 Pandemic: A Consensus Statement. JAMA Netw. Open 2021, 4, e2120295. [CrossRef]

105. Maitlis, S.; Christianson, M. Sensemaking in organizations: Taking stock and moving forward. Acad. Manag. Ann. 2014, 8, 57-125. [CrossRef]

106. Pearson, C.M.; Clair, J.A. Reframing crisis management. Acad. Manag. Rev. 1998, 23, 59-76. [CrossRef]

107. Jackson, L. Humility and vulnerability, or leaning in? Personal reflections on leadership and difference in global universities. Univ. Intellect. 2021, 1, 24-29. Available online: https://cerc.edu.hku.hk/wp-content/uploads/Humility-and-Vulnerability-orLeaning-in_-Personal-Reflections-on-Leadership-and-Difference-in-Global-Universities-Universities-Intellectuals-1-1-24-29. pdf (accessed on 10 December 2021).

108. Kirk-Jenkins, A.J.; Hughey, A.W. Abrupt Adaption: A Review of the Impact of the COVID-19 Pandemic on Faculty in Higher Education. J. Profr. 2021, 12. Available online: https://caarpweb.org/wp-content/uploads/2021/04/abrupt_adaption-Jenkins12-1.pdf (accessed on 10 December 2021).

109. Naim, A. Application of Quality Matters in Digital Learning in Higher Education. Tex. J. Multidiscip. Stud. 2021, 1, 3-12. Available online: https:/ / zienjournals.com/index.php/tjm/article/download/11/13 (accessed on 10 December 2021).

110. Rippy, M.; Munoz, M. Designing Authentic Online Courses Intra-and Post-Pandemic. In Online Teaching and Learning in Higher Education during COVID-19; Chan, R.Y., Bista, K., Allen, R.M., Eds.; Routledge: New York, NY, USA, 2021; pp. 13-27.

111. Liu, Z.; Venkatesh, S.; Murphy, S.E.; Riggio, R.E. Leader development across the lifespan: A dynamic experiences-grounded approach. Leadersh. Q. 2021, 32, 101382. [CrossRef]

112. Kono, K.G.; Taylor, S. Using an Ethos of Care to Bridge the Digital Divide: Exploring Faculty Narratives During a Global Pandemic. Online Learning 2021, 25, 151-165. Available online: https:// pdxscholar.library.pdx.edu/cgi/viewcontent.cgi?article= 1094\&context=studies_fac (accessed on 10 December 2021). [CrossRef] 
113. Kaluza, A.J.; Weber, F.; van Dick, R.; Junker, N.M. When and how health-oriented leadership relates to employee well-being-The role of expectations, self-care, and LMX. J. Appl. Soc. Psychol. 2021, 51, 404-424. [CrossRef]

114. Hofmeyer, A.; Taylor, R. Strategies and resources for nurse leaders to use to lead with empathy and prudence so they understand and address sources of anxiety among nurses practicing in the era of COVID-19. J. Clin. Nurs. 2021, 30, 298-305. [CrossRef]

115. Wahyuni, W.; Komariah, A. Management of Distance Learning in Rural Areas in the Era of the COVID-19 Pandemic. In Proceedings of the 4th International Conference on Research of Educational Administration and Management (ICREAM 2020); Atlantis Press: London, UK, 2021; pp. 444-448. Available online: https://www.atlantis-press.com/article/125952679.pdf (accessed on 10 December 2021). [CrossRef] 